\title{
Gender differences in business performance: evidence from the Characteristics of Business Owners survey
}

\author{
Robert W. Fairlie • Alicia M. Robb
}

Accepted: 9 January 2009/Published online: 5 May 2009

(C) The Author(s) 2009. This article is published with open access at Springerlink.com

\begin{abstract}
Using confidential microdata from the U.S. Census Bureau, we investigate the performance of female-owned businesses, making comparisons to male-owned businesses. Using regression estimates and a decomposition technique, we explore the role that human capital, especially through prior work experience, and financial capital play in contributing to why female-owned businesses have lower survival rates, profits, employment, and sales. We find that female-owned businesses are less successful than male-owned businesses because they have less startup capital, less business human capital acquired through prior work experience in a similar business, and less prior work experience in a family business. We also find some evidence that female business owners work fewer hours and may have different preferences for the goals of their businesses, which may have implications for business outcomes.
\end{abstract}

Keywords Business outcomes .

Female entrepreneurship

JEL Classifications J15 $\cdot$ L26

R. W. Fairlie $(\bowtie) \cdot$ A. M. Robb

Department of Economics, Engineering 2 Building, University of California, Santa Cruz, CA 95064, USA e-mail: rfairlie@ucsc.edu

A. M. Robb

e-mail: arobb@ucsc.edu

\section{Introduction}

Although female business ownership rates have risen in recent decades, the prevalence of business ownership among women is only $50-60 \%$ of that for men. The low rate of business ownership among women is a worldwide phenomenon. Aggregate data from the Organization for Economic Co-operation and Development (OECD) indicate that female self-employment rates are substantially lower than male rates in almost every reported country, with an average ratio of 0.543 (OECD 2002). In the USA, the female business ownership rate is $6.6 \%$, which is only $60 \%$ of the male rate (Fairlie 2006).

Although data with large samples of femaleowned businesses are scarce, a handful of previous studies have used business-level data to study the outcomes of female-owned firms. These studies have revealed that women-owned firms were more likely to close and had lower levels of sales, profits, and employment (Kalleberg and Leicht 1991; Rosa et al. 1996; Robb 2002; Robb and Wolken 2002). Some of the differences are dramatic: as we shall see below, estimates from the Characteristics of Business Owners (CBO) survey indicate that the sales of femaleowned firms are roughly $80 \%$ lower than the average sales of male-owned firms. See Gatewood et al. (2003) for a comprehensive review of the literature and Coleman (2001) for a discussion of constraints faced by female-owned firms. 
We know relatively little about why female-owned businesses might underperform, relative to maleowned businesses. The previous studies on differences in firm performance by gender found that financial capital, education, and work experience may be important factors. Another line of research investigates whether women access different business and investment social networks than men, which could affect outcomes (Brush et al. 2004).

In this paper, we use confidential and restrictedaccess microdata from the CBO to explore the role that human capital, financial capital, and other factors play in contributing to the relative lack of success of female-owned businesses. The CBO contains a large sample of female-owned businesses and detailed information on the characteristics of both the business and the owner, but has been used by only a handful of researchers, primarily because of difficulties obtaining access to and using and reporting results from the data. ${ }^{1}$ Estimates from the $\mathrm{CBO}$ indicate that female firms have lower survival rates, profits, employment and sales than male firms. To identify the underlying causes of these particular differences in business outcomes, we first explore the determinants of business success. We estimate logit and linear regression models for several business outcomes to identify the owner and firm characteristics that predict business success. Next, we employ a decomposition technique that identifies whether a particular factor is important, as well as how much of the gap the factor explains in a particular outcome. Using these methods, we are able to compare the relative contributions of gender differences in startup capital, human capital, and other factors in explaining why female-owned businesses have worse average outcomes than male-owned businesses.

We also explore the possibility that hours worked in the business are partly responsible, and whether preferences contribute to the difference. Robb (2000) found that gender differences in hours worked and reasons for entering into business ownership explained part of the lower survival prospects of employer firms owned by women. Another interesting finding is that a lower percentage of young women than men report a

\footnotetext{
1 All research using the CBO must be conducted in a Census Research Data Center or at the Center for Economic Studies (CES) after approval by the CES and Internal Revenue Service (IRS), and all output must pass strict disclosure regulations.
}

desire for being self-employed in the USA (Kourilsky and Walstad 1998). Using a combined sample from many countries, Blanchflower et al. (2001) also find a lower probability of preferring self-employment among women after controlling for other factors. In both cases, however, the differences are not large and represent roughly 15 percentage points. Although it is beyond the scope of this paper to do so, these data may be used to suggest policy action around increasing female-owned business success.

\section{Data}

The 1992 CBO survey was conducted by the U.S. Bureau of the Census to provide economic, demographic, and sociological data on business owners and their business activities (see Bates 1990; U.S. Census Bureau 1997; Headd 1999; Robb 2000 for more details on the $\mathrm{CBO}$ ). It includes oversamples of black-, Hispanic-, other minority- (which is primarily Asian), and female-owned businesses. The survey was sent to more than 75,000 firms and 115,000 owners who filed an Internal Revenue Service (IRS) form 1040 Schedule C (individual proprietorship or self-employed person), 1065 (partnership), or $1120 \mathrm{~S}$ (subchapter S corporation). Only firms with US $\$ 500$ or more in sales were included. The universe from which the CBO sample was drawn represents nearly $90 \%$ of all businesses in the USA (U.S. Census Bureau 1996). Response rates for the firm and owners surveys were approximately $60 \%$. All estimates reported in this article use sample weights that adjust for survey non-response (Headd 1999). ${ }^{2}$

The CBO is unique in that it contains detailed information on both the characteristics of business owners and the characteristics of their businesses. For example, owner characteristics include education, detailed work experience, hours worked in the

\footnotetext{
$\overline{2}$ Although sample weights are used that correct for nonresponse, there is some concern that closure rates are underestimated for the period from 1992 to 1996. Many businesses closed or moved over this period and did not respond to the survey which was sent out at the end of the period. Indeed, Robb (2000) showed, through matching administrative records, that nonrespondents had a much higher rate of closure than respondents. Gender differences in closure rates, however, were similar for the respondent and nonrespondent samples.
} 
business, marital status, age, weeks and hours worked, personal income, and how the business was acquired. Business characteristics include closure, profits, sales, employment, industry, startup capital, types of customers, health plans, and exports. Most business characteristics refer to 1992, with the main exception being closure, which is measured over the period 1992-1996. Additional advantages of the CBO over other nationally representative data sets for this analysis are the availability of measures of financing at startup and the large oversample of female-owned businesses. Finally, the CBO allows one to explore the causes of gender differences in several business outcomes, such as closure rates, sales, profits, and employment size, instead of focusing solely on selfemployment earnings.

The sample used for our analysis includes firms that meet a minimum weeks and hours restriction. Specifically, at least one owner must report working for the business at least 12 weeks in 1992 and at least $10 \mathrm{~h} /$ week. These restrictions exclude $22.1 \%$ of firms in the original sample. The weeks and hours restrictions are imposed to rule out very small-scale business activities, such as casual or side-businesses owned by wage/salary workers; they also allow us to check the sensitivity of our main results.

\section{Gender differences in small business outcomes}

Table 1 reports estimates of closure rates between 1992 and 1996, and 1992 profits, employment size, and sales for female- and male-owned firms from the
CBO. The magnitude of the differences in business outcomes is striking. For example, only $17.3 \%$ of female-owned firms have annual profits of US $\$ 10,000$ or more, compared with $36.4 \%$ of male-owned firms. Female-owned firms also have lower survival rates than male-owned firms. The average probability of a business closure between 1992 and 1996 is 24.4\% for female-owned firms, compared with $21.6 \%$ for maleowned firms.

Female-owned firms are substantially smaller on average than are male-owned firms. The mean of $\log$ sales among female-owned firms was 9.57 in 1992, compared with 10.36 for firms owned by men. Female-owned firms are also less likely to have employees than firms owned by men. Seventeen percent of female-owned firms hire employees, compared with $23.7 \%$ of male-owned firms. Average employment is also much smaller among femaleowned firms than among male-owned firms.

Firms owned by men are also much more likely to have larger sales than firms owned by women. Figure 1 presents $\mathrm{CBO}$ data showing the distribution of firms by receipts size, indicating that firms owned by men have higher levels of receipts than those owned by women. Women-owned firms are much more apt than male-own firms to have receipts of less than US $\$ 5,000$.

In summary, estimates from the $\mathrm{CBO}$ indicate that female-owned businesses are more likely to close, less likely to have profits of at least US $\$ 10,000$, and less likely to hire employees than businesses owned by men. Female firms also have mean annual sales that are roughly $80 \%$ of male levels.

Table 1 Business outcomes by gender Characteristics of Business Owners, 1992

\begin{tabular}{lll}
\hline Business outcomes & Female-owned & Male-owned firms \\
\hline Firm no longer operating in 1996 (Closure) & $24.4 \%$ & $21.6 \%$ \\
Positive profits & $68.5 \%$ & $77.4 \%$ \\
Net profit of at least US\$10,000 & $17.3 \%$ & $36.4 \%$ \\
One or more paid employees & $16.4 \%$ & $23.7 \%$ \\
Average employment & 1.43 & 1.94 \\
Log sales & 9.57 & 10.36 \\
Sample size & 13,918 & 24,102 \\
\hline
\end{tabular}

The sample includes businesses that are classified by the Internal Revenue Service (IRS) as individual proprietorships or selfemployed persons, partnerships, and subchapter S corporations, have sales of US\$500 or more, and have at least one owner who worked at least 12 weeks and $10 \mathrm{~h} /$ week in the business

All estimates are calculated using sample weights provided by the Characteristics of Business Owners (CBO) survey 
Fig. 1 Distribution of firms by receipts size. Source: Characteristics of Business Owners (CBO) 1992 survey (color figure online)

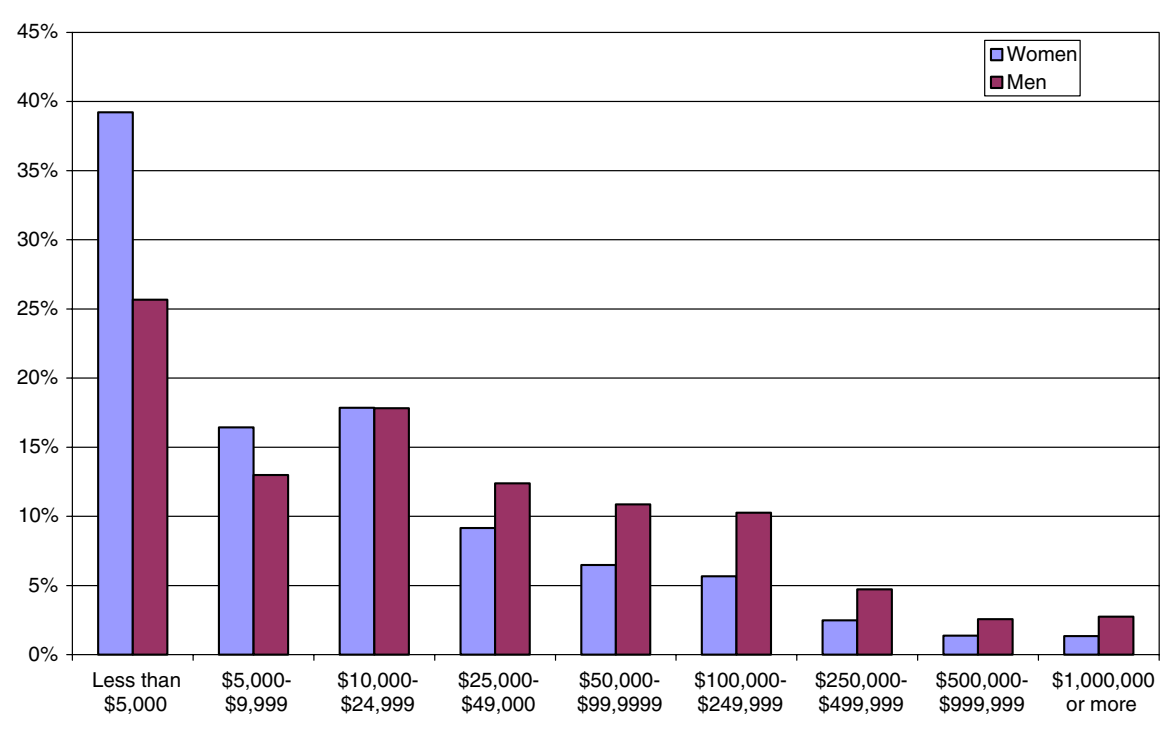

Previous studies of female/male disparities in business performance indicate similar results. For example, Srinivasan et al. (1994) use data from the National Federation of Independent Business (NFIB), finding that women-owned firms have a higher probability of closure and a lower probability of growth than male-owned firms. Using 1992 Survey of Minority-Owned Business Enterprises (SMOBE) and CBO data, Robb (2000) finds that women own just over onequarter of businesses with employees and generate less than $20 \%$ of employer firm receipts. Woman-owned firms are also found to have lower survival rates than male-owned firms. Using earlier CBO data, Boden and Nucci (2000) find that businesses owned by women are less likely to survive than businesses owned by men in both years. ${ }^{3}$ Using the longitudinal Kauffman Firm Survey data on new firms, Robb (2008) finds firms owned by women have lower sales, profits, employment, and survival rates than those owned by men.

\section{Identifying the determinants of small business outcomes}

In this study, we focus on the factors measurable with CBO microdata, such as human capital, business human capital, and financial capital. The standard

\footnotetext{
3 These findings are also consistent with evidence from household surveys indicating large differences in earnings between self-employed men and women (Aronson 1991; Devine 1994; Hundley 2000; U.S. Bureau of Labor Statistics 2004).
}

economic model predicts that these factors are important inputs in a firm's production process. The models we estimate are relatively parsimonious specifications that focus on the more exogenous owner and firm characteristics that predict business success. Once the owner and firm characteristics that are associated with business success are identified, we can use the rich $\mathrm{CBO}$ data to estimate how gender differences in these factors contribute to female/male differences in business outcomes.

The CBO data contain information on four major business outcomes-closure, profits, employment, and sales. Although none of these measures alone represents a perfect, universally agreed upon measure of business success, taken together they provide a fairly comprehensive picture of what it means to be successful in business. Logit and linear regression models are estimated for the probability of a business closure from 1992 to 1996 , the probability that the firm has profits of at least US $\$ 10,000$ per year, the probability of having employees, and $\log$ sales. ${ }^{4}$ Table 2 reports estimates of marginal effects for the logit regressions and coefficients for the ordinary least squares (OLS) regression. Because of concerns regarding potential endogeneity, we follow the

\footnotetext{
${ }^{4}$ The profit measure available in the $\mathrm{CBO}$ is categorical. We estimate a logit model for the cutoff of US\$10,000 to make it easier to interpret the coefficients and perform the decomposition described below. We also find similar results in estimating an ordered probit for all categories of profits which is reported in Specification 5 of Table 2.
} 
approach taken in many previous studies of selfemployment, reporting estimates from separate sets of regression models that exclude and include startup capital and industry controls. ${ }^{5}$ We discuss the results without startup capital and industry controls first.

Race and ethnicity are important determinants of small business outcomes. ${ }^{6}$ In the regressions, white is the excluded race category, and the included dummy variables are black, Hispanic, Native-American, and Asian. Thus, the interpretation of the coefficient on each variable is the remaining difference between whites and that minority group in the business outcome. For example, the coefficient on the blackowned business variable in Specification 3 implies that black-owned firms are 9.51 percentage points less likely to hire an employee than are white-owned firms, even after controlling for differences in other variables included in the regressions. After controlling for numerous owner and business characteristics, black-owned businesses continue to lag behind whiteowned businesses. In all specifications except the closure probability equation, the coefficient estimate on the black-owned business dummy variable is large, positive, and statistically significant. In the closure probability equation, the coefficient estimate is positive, but statistically insignificant. The results are more mixed for Latino-owned firms. They have a lower probability of having large profits, but have a higher probability of hiring employees than whiteowned firms. The coefficient estimates in the other two specifications are statistically insignificant. Asian- and Native American-owned businesses generally have better outcomes than white-owned businesses after controlling for the included variables. However, in the next set of regressions, which include startup capital and industry controls, the positive Asian coefficients essentially disappear. The black coefficients also become noticeably smaller after the inclusion of these additional variables.

Female-owned businesses continue to have lower measures of business outcomes than male-owned businesses after controlling for the included owner and business characteristics. The finding of relatively

\footnotetext{
$\overline{5}$ The concern is that low levels of startup capital and industry choice may be partly determined by the ability of the entrepreneur.

${ }^{6}$ See Fairlie and Robb (2007b, 2008) for more details on racial differences in business outcomes.
}

large and statistically significant coefficients on all of the female dummy variables indicates that the included controls for education, family background, work experience, and other owner and firm characteristics cannot entirely explain gender differences in business outcomes. By comparing these to the original gender differences in the business outcomes reported in Table 1, we can get a sense of how much of the gender disparities in business outcomes are explained by gender differences in all of the included owner and business characteristics. However, the current estimates do not reveal the relative importance of each of the owner and business characteristics in explaining gender differences in business outcomes. Before addressing this question, we will continue the general discussion of identifying the determinants of business outcomes.

Similar to previous studies, we find that small business outcomes are positively associated with the education level of the business owner (Bates 1997; Astebro and Bernhardt 2003; Headd 2003; Robb 2008). Estimates from the CBO indicate that owner's education improves all four of the available business outcomes. For example, compared with businesses with owners that have dropped out of high school, businesses with college-educated owners are 5.5 percentage points less likely to close, 11.3 percentage points more likely to have profits of US\$10,000 or more, and 6.1 percentage points more likely to have employees, and they have approximately $25 \%$ higher sales. Owners who have completed graduate school are 10.4 percentage points more likely to hire employees and have sales that are roughly $37 \%$ higher than those of businesses owned by college graduates. In fact, we generally see better business outcomes with each higher level of education.

Also, firms located in urban areas are more likely to close and are less likely to have employees, but are more likely to have large profits and have higher sales than firms located in non-urban areas. Previous work experience has mixed effects across outcome measures, although we find some evidence that suggests individuals with 20 or more years or very few years of prior work experience have worse outcomes, on average.

Having a family business background is important for small business outcomes (see Fairlie and Robb 2007a for more details). The main effect, however, appears to be through the informal learning or 
Table 2 Logit, linear, and ordered probit regressions for small business outcomes Characteristics of Business Owners, 1992

\begin{tabular}{|c|c|c|c|c|c|}
\hline \multirow[t]{2}{*}{ Variables/determinants } & \multicolumn{5}{|l|}{ Specification } \\
\hline & (1) & (2) & (3) & (4) & $(5)$ \\
\hline Dependent variable & $\begin{array}{l}\text { Closure } \\
(1992-1996)\end{array}$ & Profits $\$ 10,000+$ & Employer firm & Ln sales & Profits ordered \\
\hline Black-owned business & $\begin{array}{l}0.0212 \\
(0.0130)\end{array}$ & $\begin{array}{l}-0.1786^{*} \\
(0.0207)\end{array}$ & $\begin{array}{l}-0.0951 * \\
(0.0166)\end{array}$ & $\begin{array}{l}-0.4636^{*} \\
(0.0554)\end{array}$ & $\begin{array}{l}-0.4160 * \\
(0.0166)\end{array}$ \\
\hline Latino-owned business & $\begin{array}{l}-0.0138 \\
(0.0121)\end{array}$ & $\begin{array}{l}-0.0443^{*} \\
(0.0144)\end{array}$ & $\begin{array}{l}0.0231 * \\
(0.0116)\end{array}$ & $\begin{array}{l}0.0660 \\
(0.0490)\end{array}$ & $\begin{array}{l}-0.0966^{*} \\
(0.0318)\end{array}$ \\
\hline Native American-owned business & $\begin{array}{l}-0.1176^{*} \\
(0.0554)\end{array}$ & $\begin{array}{l}0.0422 \\
(0.0530)\end{array}$ & $\begin{array}{l}0.0717 \\
(0.0415)\end{array}$ & $\begin{array}{l}0.3991 * \\
(0.1879)\end{array}$ & $\begin{array}{l}0.0654 \\
(0.1207)\end{array}$ \\
\hline Asian-owned business & $\begin{array}{l}-0.0457 * \\
(0.0145)\end{array}$ & $\begin{array}{l}0.0259 \\
(0.0145)\end{array}$ & $\begin{array}{l}0.0728 * \\
(0.0145)\end{array}$ & $\begin{array}{l}0.4709 * \\
(0.0539)\end{array}$ & $\begin{array}{l}0.0004 \\
(0.0340)\end{array}$ \\
\hline Female-owned business & $\begin{array}{l}0.0247 * \\
(0.0050)\end{array}$ & $\begin{array}{l}-0.2107 * \\
(0.0066)\end{array}$ & $\begin{array}{l}-0.0616^{*} \\
(0.0051)\end{array}$ & $\begin{array}{l}-0.6941^{*} \\
(0.0206)\end{array}$ & $\begin{array}{l}-0.3968 * \\
(0.0135)\end{array}$ \\
\hline High school graduate & $\begin{array}{l}-0.0209 * \\
(0.0085)\end{array}$ & $\begin{array}{l}0.0624 * \\
(0.0112)\end{array}$ & $\begin{array}{l}0.0447 * \\
(0.0092)\end{array}$ & $\begin{array}{l}0.1534 * \\
(0.0351)\end{array}$ & $\begin{array}{l}0.0209 \\
(0.0234)\end{array}$ \\
\hline Some college & $\begin{array}{l}-0.0101 \\
(0.0084)\end{array}$ & $\begin{array}{l}0.0724 * \\
(0.0111)\end{array}$ & $\begin{array}{l}0.0471 * \\
(0.0091)\end{array}$ & $\begin{array}{l}0.0570 \\
(0.0351)\end{array}$ & $\begin{array}{l}0.1038 * \\
(0.0232)\end{array}$ \\
\hline College graduate & $\begin{array}{l}-0.0553 * \\
(0.0093)\end{array}$ & $\begin{array}{l}0.1133 * \\
(0.0118)\end{array}$ & $\begin{array}{l}0.0606 * \\
(0.0097)\end{array}$ & $\begin{array}{l}0.2397 * \\
(0.0383)\end{array}$ & $\begin{array}{l}0.1632 * \\
(0.0252)\end{array}$ \\
\hline Graduate school & $\begin{array}{l}-0.1491^{*} \\
(0.0107)\end{array}$ & $\begin{array}{l}0.2127 * \\
(0.0122)\end{array}$ & $\begin{array}{l}0.1650 * \\
(0.0097)\end{array}$ & $\begin{array}{l}0.6115 * \\
(0.0404)\end{array}$ & $\begin{array}{l}0.5130 * \\
(0.0267)\end{array}$ \\
\hline Urban & $\begin{array}{l}0.0164 * \\
(0.0058)\end{array}$ & $\begin{array}{l}0.0447 * \\
(0.0069)\end{array}$ & $\begin{array}{l}-0.0343 * \\
(0.0055)\end{array}$ & $\begin{array}{l}0.1008 * \\
(0.0234)\end{array}$ & $\begin{array}{l}0.1134 * \\
(0.0150)\end{array}$ \\
\hline Prior work experience in a managerial capacity & $\begin{array}{l}0.0655^{*} \\
(0.0054)\end{array}$ & $\begin{array}{l}0.0265^{*} \\
(0.0063)\end{array}$ & $\begin{array}{l}0.0513 * \\
(0.0052)\end{array}$ & $\begin{array}{l}0.2089 * \\
(0.0217)\end{array}$ & $\begin{array}{l}-0.0055 \\
(0.0141)\end{array}$ \\
\hline Prior work experience in a similar business & $\begin{array}{l}-0.0425^{*} \\
(0.0049)\end{array}$ & $\begin{array}{l}0.1024 * \\
(0.0059)\end{array}$ & $\begin{array}{l}0.0432 * \\
(0.0048)\end{array}$ & $\begin{array}{l}0.4087 * \\
(0.0202)\end{array}$ & $\begin{array}{l}0.2484 * \\
(0.0131)\end{array}$ \\
\hline Have a self-employed family member & $\begin{array}{l}-0.0200 * \\
(0.0055)\end{array}$ & $\begin{array}{l}0.0113 \\
(0.0067)\end{array}$ & $\begin{array}{l}-0.0022 \\
(0.0055)\end{array}$ & $\begin{array}{l}-0.0356 \\
(0.0227)\end{array}$ & $\begin{array}{l}0.0092 \\
(0.0148)\end{array}$ \\
\hline Prior work experience in a family member's business & $\begin{array}{l}-0.0419 * \\
(0.0069)\end{array}$ & $\begin{array}{l}0.0322 * \\
(0.0079)\end{array}$ & $\begin{array}{l}0.0552 * \\
(0.0063)\end{array}$ & $\begin{array}{l}0.3784 * \\
(0.0273)\end{array}$ & $\begin{array}{l}0.0471 * \\
(0.0178)\end{array}$ \\
\hline Inherited business & $\begin{array}{l}-0.1007 * \\
(0.0237)\end{array}$ & $\begin{array}{l}0.1097 * \\
(0.0217)\end{array}$ & $\begin{array}{l}0.2006 * \\
(0.0157)\end{array}$ & $\begin{array}{l}1.3144 * \\
(0.0800)\end{array}$ & $\begin{array}{l}0.3524 * \\
(0.0506)\end{array}$ \\
\hline Mean of dependent variable & 0.2280 & 0.2980 & 0.2070 & 10.0725 & 1.2391 \\
\hline Log likelihood $/ R^{2}$ & $-17,466.46$ & $-16,957.14$ & $-16,542.74$ & 0.1119 & $-40,045.16$ \\
\hline Sample size & 33,485 & 30,500 & 34,179 & 34,179 & 30,500 \\
\hline
\end{tabular}

See notes to Table 1

Marginal effects and their standard errors (in parenthesis) are reported for the logit regressions

Logit models are used for Specifications 1-3, ordinary least squares analysis is used for Specification 4, and an ordered probit is used for Specification 5. The log likelihood value is reported for the logit and ordered probit regressions and $R^{2}$ is reported for the OLS model

All specifications also include a constant, and dummy variables for marital status of primary owner, region, and work experience of the primary owner 
apprenticeship type training that occurs in working in a family business and not from simply having a selfemployed family member. The coefficient estimates on the dummy variable indicating whether the owner had a family member who owned a business are small and statistically insignificant in all of the specifications except for the closure probability equation. In contrast, working at this family member's business has a large positive and statistically significant effect in all specifications. The probability of a business closure is 0.042 lower, the probability of large profits is 0.032 higher, the probability of employment is 0.055 higher, and sales are roughly $40 \%$ higher if the business owner had worked for one of his/her selfemployed family members prior to starting the business. ${ }^{7}$ The effects on the closure, profit, and employment probabilities represent $15.3-26.6 \%$ of the sample mean for the dependent variables.

Inherited businesses are more successful and larger than non-inherited businesses. The coefficients are large, positive (negative in the closure equation), and statistically significant in all specifications. However, because inheritances only make up $1.6 \%$ of all small businesses, their importance in determining broad business outcomes is slight, and their role in the differences in business outcomes by gender is probably minor.

The CBO also provides detailed information on other forms of acquiring general and specific business human capital. Available questions include information on prior work experience in a managerial capacity and prior work experience in a business whose goods and services were similar to those provided by the owner's business. Management experience prior to starting or acquiring a business generally improves business outcomes but does not have a consistent effect across specifications. In contrast, prior work experience in a similar business, which provides specific business human capital, is an important determinant of business success. In all specifications, the coefficient estimates are large (negative in the closure equation), positive, and statistically significant.

\footnotetext{
7 These estimates are not overly sensitive to the exclusion of firms started before 1980 or the inclusion of the age of the firm (with the exception of the inheritance variable). In addition, estimates from the log sales specification are not sensitive to the exclusion of firms with extremely large annual sales.
}

We estimate a second set of small business outcome regressions that include dummy variables for different levels of startup capital and major industry categories. These estimates are reported in Table 3. As expected, business outcomes are positively associated with the amount of capital used to start the business. The coefficients on the startup capital dummies are large, positive (negative for the closure probability), and statistically significant in all specifications. In almost every specification, outcomes improve with each higher level of startup capital. The relationship between startup capital and business success is also strong for each type of business outcome. Perhaps the most interesting finding is the relationship between startup capital and closure. Firms with US\$100,000 or more in startup capital are 23.0 percentage points less likely to close than are firms with less than US\$5,000 in startup capital, and are 9.9 percentage points less likely to close than are firms with US $\$ 25,000$ $\$ 99,999$ in startup capital. These results hold even after controlling for detailed owner and firm characteristics, including business human capital and the industry of the firm. Owners who have less access to startup capital appear to start less successful businesses, which is consistent with the findings of previous studies (Bates 1997; Robb 2000; Headd 2003).

Industry is also linked to business success, as many of the dummy variables for industries are large in magnitude and statistically significant (retail trade is the left-out category). The estimates vary across specifications, however, making it difficult to summarize the association between industries and business outcomes. ${ }^{8}$

\footnotetext{
$\overline{8}$ The addition of startup capital and industry does not overly influence the estimated effects of the human capital, business human capital, and family business background variables. We also investigate whether our regression estimates are sensitive to alternative samples. First, we estimate regressions using a sample that excludes firms with less than US $\$ 5,000$ in startup capital. We do not use this restriction in the original sample because most businesses report requiring very little in startup capital and, in fact, many large successful businesses started with virtually no capital, and because of concerns that the receipt of startup capital may be related to the potential success of the business (see Fairlie and Robb 2007a). Although mean outcomes among businesses that started with US\$5,000 or more in startup capital are better than those for all businesses, we find roughly similar estimates for most variables in the
} 


\section{Gender differences in human capital, financial capital, and other characteristics}

The regression analysis identifies several owner and firm characteristics that are strongly associated with business outcomes. The next question is whether female-owned businesses and male-owned businesses differ in these characteristics. Large differences between female and male firms in the key determinants of business success will contribute to differences in business outcomes. The exact contributions are estimated and discussed in the next section.

To explore differences between female- and maleowned businesses, we first examine the owner's education level, which is found to be an important determinant of business outcomes. Female business owners are not clearly more or less educated than male business owners. As illustrated in Fig. 1, a lower percentage of female business owners are high school dropouts than male business owners $(8.3 \%$ compared with $11.6 \%$ ), but a lower percentage of female business owners have graduate degrees than male business owners (11.4\% compared with 14.8\%). In the middle of the distribution, female owners are more likely to have some college and college degrees than male owners. Overall, it is difficult to know whether female or male owners have an educational advantage in terms of business outcomes. ${ }^{9}$ The decomposition discussed below will provide direct evidence on this question.

Estimates from the $\mathrm{CBO}$ indicate that female and male primary business owners have different family

Footnote 8 continued

regression models. We also check the sensitivity of our results to the removal of part-time business owners. We estimate separate regressions that only include businesses with at least one owner who works $30 \mathrm{~h}$ or more per week and 36 weeks or more per year, which reduces the sample size by roughly $20 \%$. Although average business outcomes are also better for this sample, we find similar coefficients on most variables. We also estimate regressions that include even tighter hours and weeks work restrictions and find roughly similar results. Overall, the regression results are not sensitive to these alternative sample restrictions.

${ }^{9}$ Female business owners have a similar likelihood of having a business degree as male owners, which follows more general patterns in the population (U.S. Census Bureau 1997). Estimates from the National Center for Educational Statistics indicate that women received $49.6 \%$ and $40.7 \%$ of all Bachelor's and Master's degrees in business, respectively, conferred in 2000-2001 (U.S. Department of Education 2002). business backgrounds. Table 4 reports the percentage of owners that had a family member who was a business owner and the percentage of owners that worked for that family member. As expected, female and male business owners do not differ substantially in the percentage reporting that they had a family member who owned a business prior to starting their business. However, female business owners are less likely to have worked in the family business than male business owners. Estimates from the CBO indicate that conditional on having a self-employed family member, only $38.3 \%$ of female business owners had worked for that person's business, whereas $46.2 \%$ of male business owners who had a self-employed family member worked for that person's business. ${ }^{10}$ The result is that female business owners overall were less likely than male business owners to work for a family member's business. The unconditional rate of working for family member's business was $19.4 \%$ for women and $24.0 \%$ for men. ${ }^{11}$ Given the findings that work experience in a family business may provide important opportunities for acquiring general and specific business human capital (Lentz and Laband 1990; Fairlie and Robb 2007a), these gender differences will contribute to gender differences in business outcomes.

Inheritance was an infrequent source of business ownership, with only $1.4 \%$ of female business owners and $1.7 \%$ of male business owners citing this as the source of their businesses. As expected, the low levels of business inheritances suggest that it does not contribute substantially to gender differences in business outcomes.

Related to the family business background of the owner, being married is associated with business success. Spouses may provide financial assistance, paid or unpaid labor for the business, health insurance coverage, and other types of assistance useful for running a business. Estimates from the CBO indicate that $76.4 \%$ of female business owners are married,

\footnotetext{
${ }^{10}$ For a sample of business owners in Vancouver Canada, Aldrich et al. (1998) find that $61 \%$ of owners with selfemployed parents worked in that family business, which is in line with these estimates from the CBO.

11 Aldrich and Kim (2007) using a sample of nascent entrepreneurs and a comparison group also find that men are more likely to report working in their parent's business than are women.
} 
Table 3 Logit and linear regressions for small business outcomes Characteristics of Business Owners, 1992

\begin{tabular}{|c|c|c|c|c|}
\hline \multirow[t]{2}{*}{ Variables/determinants } & \multicolumn{4}{|l|}{ Specification } \\
\hline & (1) & (2) & (3) & (4) \\
\hline Dependent variable & $\begin{array}{l}\text { Closure } \\
(1992-1996)\end{array}$ & Profits $\$ 10,000+$ & Employer firm & Ln sales \\
\hline Black-owned business & $\begin{array}{l}0.0077 \\
(0.0133)\end{array}$ & $\begin{array}{l}-0.1684 * \\
(0.0213)\end{array}$ & $\begin{array}{l}-0.0703 * \\
(0.0176)\end{array}$ & $\begin{array}{l}-0.3215^{*} \\
(0.0506)\end{array}$ \\
\hline Latino-owned business & $\begin{array}{l}-0.0143 \\
(0.0123)\end{array}$ & $\begin{array}{l}-0.0444 * \\
(0.0149)\end{array}$ & $\begin{array}{l}0.0277 * \\
(0.0126)\end{array}$ & $\begin{array}{l}0.0735 \\
(0.0447)\end{array}$ \\
\hline Native American-owned business & $\begin{array}{l}-0.1270 * \\
(0.0564)\end{array}$ & $\begin{array}{l}0.0322 \\
(0.0548)\end{array}$ & $\begin{array}{l}0.0696 \\
(0.0548)\end{array}$ & $\begin{array}{l}0.3468 * \\
(0.1706)\end{array}$ \\
\hline Asian-owned business & $\begin{array}{l}-0.0091 \\
(0.0149)\end{array}$ & $\begin{array}{l}-0.0176 \\
(0.0150)\end{array}$ & $\begin{array}{l}-0.0164 \\
(0.0128)\end{array}$ & $\begin{array}{l}0.0216 \\
(0.0150)\end{array}$ \\
\hline Female-owned business & $\begin{array}{l}0.0150 * \\
(0.0053)\end{array}$ & $\begin{array}{l}-0.1943 * \\
(0.0069)\end{array}$ & $\begin{array}{l}-0.0498 * \\
(0.0057)\end{array}$ & $\begin{array}{l}-0.5708^{*} \\
(0.0193)\end{array}$ \\
\hline High school graduate & $\begin{array}{l}-0.0065 \\
(0.0087)\end{array}$ & $\begin{array}{l}0.0428 * \\
(0.0116)\end{array}$ & $\begin{array}{l}0.0251 * \\
(0.0099)\end{array}$ & $\begin{array}{l}0.0324 \\
(0.0325)\end{array}$ \\
\hline Some college & $\begin{array}{l}0.0095 \\
(0.0086)\end{array}$ & $\begin{array}{l}0.0637 * \\
(0.0115)\end{array}$ & $\begin{array}{l}0.0398 * \\
(0.0098)\end{array}$ & $\begin{array}{l}0.0011 \\
(0.0322)\end{array}$ \\
\hline College graduate & $\begin{array}{l}-0.0433^{*} \\
(0.0096)\end{array}$ & $\begin{array}{l}0.0855 * \\
(0.0123)\end{array}$ & $\begin{array}{l}0.0470 * \\
(0.0106)\end{array}$ & $\begin{array}{l}0.1441 * \\
(0.0355)\end{array}$ \\
\hline Graduate school & $\begin{array}{l}-0.1617 * \\
(0.0117)\end{array}$ & $\begin{array}{l}0.1573 * \\
(0.0137)\end{array}$ & $\begin{array}{l}0.1674 * \\
(0.0115)\end{array}$ & $\begin{array}{l}0.5567 * \\
(0.0397)\end{array}$ \\
\hline Urban & $\begin{array}{l}0.0079 \\
(0.0059)\end{array}$ & $\begin{array}{l}0.0610 * \\
(0.0071)\end{array}$ & $\begin{array}{l}-0.0144 * \\
(0.0059)\end{array}$ & $\begin{array}{l}0.1831 * \\
(0.0214)\end{array}$ \\
\hline Prior work experience in a managerial capacity & $\begin{array}{l}0.0826 * \\
(0.0056)\end{array}$ & $\begin{array}{l}0.0075 \\
(0.0066)\end{array}$ & $\begin{array}{l}0.0212 * \\
(0.0057)\end{array}$ & $\begin{array}{l}0.0401 * \\
(0.0200)\end{array}$ \\
\hline Prior work experience in a similar business & $\begin{array}{l}-0.0505^{*} \\
(0.0052)\end{array}$ & $\begin{array}{l}0.0962 * \\
(0.0061)\end{array}$ & $\begin{array}{l}0.0426 * \\
(0.0053)\end{array}$ & $\begin{array}{l}0.4081 * \\
(0.0187)\end{array}$ \\
\hline Have a self-employed family member & $\begin{array}{l}-0.0181 * \\
(0.0057)\end{array}$ & $\begin{array}{l}0.0004 \\
(0.0069)\end{array}$ & $\begin{array}{l}-0.0057 \\
(0.0060)\end{array}$ & $\begin{array}{l}-0.0651^{*} \\
(0.0207)\end{array}$ \\
\hline Prior work experience in a family member's business & $\begin{array}{l}-0.0323 * \\
(0.0071)\end{array}$ & $\begin{array}{l}0.0210 * \\
(0.0081)\end{array}$ & $\begin{array}{l}0.0344 * \\
(0.0069)\end{array}$ & $\begin{array}{l}0.2300 * \\
(0.0250)\end{array}$ \\
\hline Inherited business & $\begin{array}{l}-0.0761 * \\
(0.0246)\end{array}$ & $\begin{array}{l}0.1351^{*} \\
(0.0238)\end{array}$ & $\begin{array}{l}0.2267 * \\
(0.0182)\end{array}$ & $\begin{array}{l}1.3143^{*} \\
(0.0764)\end{array}$ \\
\hline Startup capital: $\$ 5,000-\$ 24,999$ & $\begin{array}{l}-0.0871 * \\
(0.0061)\end{array}$ & $\begin{array}{l}0.1505^{*} \\
(0.0068)\end{array}$ & $\begin{array}{l}0.1487 * \\
(0.0059)\end{array}$ & $\begin{array}{l}0.7156 * \\
(0.0214)\end{array}$ \\
\hline Startup capital: $\$ 25,000-\$ 99,999$ & $\begin{array}{l}-0.1308 * \\
(0.0090)\end{array}$ & $\begin{array}{l}0.2312 * \\
(0.0088)\end{array}$ & $\begin{array}{l}0.3077 * \\
(0.0070)\end{array}$ & $\begin{array}{l}1.4676 * \\
(0.0291)\end{array}$ \\
\hline Startup capital: $\$ 100,000$ or more & $\begin{array}{l}-0.2295^{*} \\
(0.0166)\end{array}$ & $\begin{array}{l}0.1791 * \\
(0.0125)\end{array}$ & $\begin{array}{l}0.3735 * \\
(0.0099)\end{array}$ & $\begin{array}{l}2.1520 * \\
(0.0422)\end{array}$ \\
\hline Agricultural services & $\begin{array}{l}0.0112 \\
(0.0164)\end{array}$ & $\begin{array}{l}-0.0111 \\
(0.0184)\end{array}$ & $\begin{array}{l}-0.1586^{*} \\
(0.0167)\end{array}$ & $\begin{array}{l}-0.9204 * \\
(0.0574)\end{array}$ \\
\hline Mining and construction & $\begin{array}{l}0.0438 * \\
(0.0096)\end{array}$ & $\begin{array}{l}0.0528 * \\
(0.0111)\end{array}$ & $\begin{array}{l}-0.0353 * \\
(0.0111)\end{array}$ & $\begin{array}{l}-0.2546^{*} \\
(0.0350)\end{array}$ \\
\hline
\end{tabular}


Table 3 continued

\begin{tabular}{|c|c|c|c|c|}
\hline \multirow[t]{2}{*}{ Variables/determinants } & \multicolumn{4}{|c|}{ Specification } \\
\hline & (1) & (2) & (3) & (4) \\
\hline Manufacturing & $\begin{array}{l}-0.0625^{*} \\
(0.0171)\end{array}$ & $\begin{array}{l}0.0358 * \\
(0.0166)\end{array}$ & $\begin{array}{l}0.0035 \\
(0.0129)\end{array}$ & $\begin{array}{l}-0.1055^{*} \\
(0.0532)\end{array}$ \\
\hline Wholesale & $\begin{array}{l}0.0057 \\
(0.0148)\end{array}$ & $\begin{array}{l}0.1305 \\
(0.0153)^{*}\end{array}$ & $\begin{array}{l}-0.0006 \\
(0.0127)\end{array}$ & $\begin{array}{l}0.6082 * \\
(0.0518)\end{array}$ \\
\hline FIRE & $\begin{array}{l}-0.0609 * \\
(0.0109)\end{array}$ & $\begin{array}{l}0.0771 * \\
(0.0122)\end{array}$ & $\begin{array}{l}-0.1856 * \\
(0.0109)\end{array}$ & $\begin{array}{l}-0.4926^{*} \\
(0.0367)\end{array}$ \\
\hline Trans., communications, and public utilities & $\begin{array}{l}0.0600^{*} \\
(0.0130)\end{array}$ & $\begin{array}{l}0.1205^{*} \\
(0.0147)\end{array}$ & $\begin{array}{l}-0.1523 * \\
(0.0139)\end{array}$ & $\begin{array}{l}-0.3300^{*} \\
(0.0486)\end{array}$ \\
\hline Personal services & $\begin{array}{l}0.0195 * \\
(0.0079)\end{array}$ & $\begin{array}{l}-0.0488 * \\
(0.0096)\end{array}$ & $\begin{array}{l}-0.1161 * \\
(0.0077)\end{array}$ & $\begin{array}{l}-0.7430 * \\
(0.0286)\end{array}$ \\
\hline Professional services & $\begin{array}{l}0.0973 * \\
(0.0089)\end{array}$ & $\begin{array}{l}0.0650^{*} \\
(0.0110)\end{array}$ & $\begin{array}{l}-0.1191 * \\
(0.0092)\end{array}$ & $\begin{array}{l}-0.7021^{*} \\
(0.0328)\end{array}$ \\
\hline Uncoded industry & $\begin{array}{l}0.0198 \\
(0.0132)\end{array}$ & $\begin{array}{l}-0.1020^{*} \\
(0.0183)\end{array}$ & $\begin{array}{l}-0.5054 * \\
(0.0334)\end{array}$ & $\begin{array}{l}-0.9842 * \\
(0.0490)\end{array}$ \\
\hline Mean of dependent variable & 0.2280 & 0.2975 & 0.2066 & 10.0668 \\
\hline Sample size & 33,116 & 30,271 & 33,701 & 33,701 \\
\hline
\end{tabular}

See notes to Table 1

Logit models are used for Specifications 1-3 and OLS is used for Specification 4

Marginal effects and their standard errors (in parenthesis) are reported

All specifications also include a constant, and dummy variables for marital status of primary owner, region, and work experience of the primary owner

Table 4 Previous business experience and family business background by gender Characteristics of Business Owners, 1992

\begin{tabular}{lrr}
\hline Previous business experience/family business background & $\begin{array}{l}\text { Female-owned } \\
\text { Firms }\end{array}$ & $\begin{array}{c}\text { Male-owned } \\
\text { Firms }\end{array}$ \\
\hline Percentage of owners that had a self-employed family member prior to starting firm & 50.6 & 52.0 \\
Percentage of owners that previously worked in that family member's business (conditional) & 38.3 & 46.2 \\
Percentage of owners that previously worked in a family member's business (unconditional) & 19.4 & 1.4 \\
Percentage of owners that inherited their businesses & 42.5 & 52.3 \\
Percentage of owners that previously worked in a business with similar goods/services & 53.8 \\
Percentage of owners that have previous work experience in a managerial capacity & 13,918 & 56.6 \\
Sample size & 24,102 \\
\hline
\end{tabular}

The sample includes businesses that are classified by the IRS as individual proprietorships or self-employed persons, partnerships and subchapter S corporations, have sales of US $\$ 500$ or more, and have at least one owner who worked at least 12 weeks and $10 \mathrm{~h} /$ week in the business

All estimates are calculated using sample weights provided by the CBO

compared with $81.7 \%$ of male business owners (see Appendix).

For other types of business human capital, estimates from $\mathrm{CBO}$ microdata indicate that female and male business owners have roughly similar management experience. As indicated in Table 4, $52.3 \%$ of female business owners and $56.6 \%$ of male business owners have previous work experience in a managerial capacity prior to owning their current business. This type of experience provides an 
opportunity to gain professional and management experience useful in running future business ventures.

Although managerial experience in general is roughly similar, female business owners have much less prior work experience working in business(es) similar to their own. Forty-two percent of female business owners previously worked in a business that provided similar goods or services as the businesses they currently own; the rate for male business owners was $53.8 \%$. As noted above, the effects of this type of prior work experience are large, and thus may explain part of the gender gap in business performance.

Although not reported, the regression models also included a measure of the number of years of work experience prior to starting the business. We find similar distributions of years of prior work experience by gender. The effects across outcome measures for this variable are also mixed, suggesting that it cannot contribute substantially to gender difference in outcomes.

Estimates from the $\mathrm{CBO}$ indicate that women started their businesses with less capital than men. Figure 2 indicates that for each level of startup capital above US $\$ 5,000$, there are a lower percentage of female-owned businesses than male-owned businesses. The difference, however, at the highest startup capital level $(\$ 100,000$ and more) is relatively small. For women, $4.1 \%$ started with more than US $\$ 100,000$ in capital compared with $5.5 \%$ of male- owned businesses. Slightly more than two-thirds of female-owned firms were started with less than US $\$ 5,000$ compared with $56.7 \%$ of male-owned firms.

Table 5 shows the distribution of firms by industry for female and male-owned firms. Female firms are much less frequently found in construction than male firms. The difference is large-only $3.3 \%$ of female firms are in construction, compared with $16.3 \%$ of male firms. On the other hand, female-owned businesses are more likely to be found in retail trade, personal services, and professional services than male-owned businesses. The decompositions in the next section will shed light on whether these industry differences contribute to differences in business outcomes.

\section{Explanations for gender differences in business outcomes}

Estimates from the $\mathrm{CBO}$ indicate that female business owners differ from male owners for many characteristics, such as prior work experience and industry. The estimates reported in Tables 2 and 3 also indicate that many of these variables are important determinants of small business outcomes. Taken together, these results suggest that gender differences in prior work experience and startup
Fig. 2 Education level of owner by gender. Source: CBO 1992 survey (color figure online)

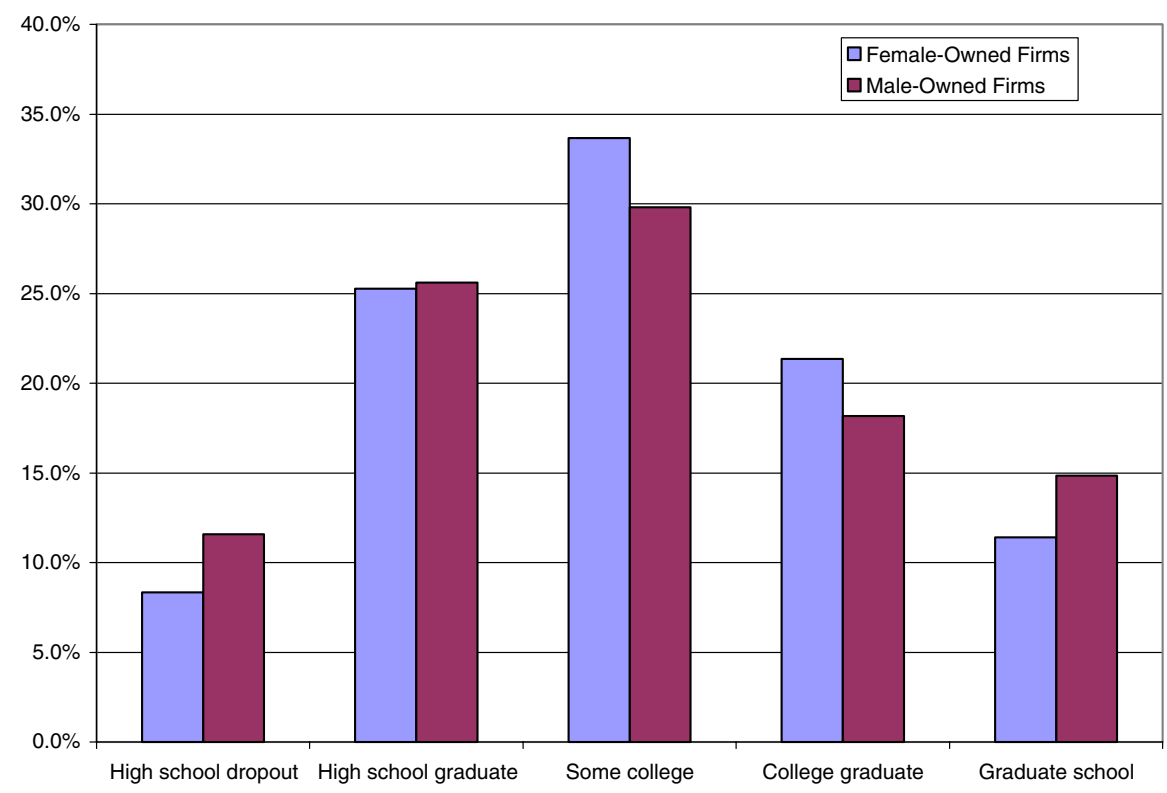


Table 5 Industry distribution by gender Characteristics of Business Owners, 1992

\begin{tabular}{lrr}
\hline Industry distribution & Female-owned firms & Male-owned firms \\
\hline Agricultural services & $1.7 \%$ & $3.2 \%$ \\
Construction & $3.3 \%$ & $16.3 \%$ \\
Manufacturing & $2.9 \%$ & $3.5 \%$ \\
Wholesale trade & $3.0 \%$ & $3.8 \%$ \\
Retail trade & $18.9 \%$ & $13.1 \%$ \\
Finance, insurance and real estate & $10.5 \%$ & $9.3 \%$ \\
Trans., communications, and public utilities & $2.5 \%$ & $5.0 \%$ \\
Personal services & $30.6 \%$ & $24.2 \%$ \\
Professional services & $23.0 \%$ & $17.2 \%$ \\
Uncoded industry & $3.7 \%$ & $4.2 \%$ \\
Sample size & 13,918 & 24,102 \\
\hline
\end{tabular}

The sample includes businesses that are classified by the IRS as individual proprietorships or self-employed persons, partnerships, and subchapter S corporations, have sales of US\$500 or more, and have at least one owner who worked at least 12 weeks and $10 \mathrm{~h} /$ week in the business

All estimates are calculated using sample weights provided by the CBO

capital contribute to why female-owned businesses have worse outcomes on average than male-owned businesses. The impact of each factor, however, is difficult to summarize. In particular, we wish to identify the separate contributions from gender differences in the distributions of all of the variables or subsets of variables included in the regressions.

To explore these issues further, we employ the familiar technique of decomposing inter-group differences in a dependent variable into those due to different observable characteristics across groups and those due to different "prices" of characteristics of groups (see Blinder 1973; Oaxaca 1973). ${ }^{12}$ The standard BlinderOaxaca decomposition is used with the marginal effects from the logit specifications for closure, profits and employment, and the coefficients for the linear log sales specification. ${ }^{13}$ Similar to most recent studies applying the decomposition technique, we focus on estimating the first component of the decomposition that captures contributions from differences in

\footnotetext{
12 The standard Blinder-Oaxaca decomposition of the white/ minority gap in the average value of the dependent variable, $\mathrm{Y}$, can be expressed as: $\bar{Y}^{W}-\bar{Y}^{M}=\left\lfloor\left(\bar{X}^{W}-\bar{X}^{M}\right) \hat{\beta}^{W}\right\rfloor+\left\lfloor\bar{X}^{M}\right.$ $\left.\left(\hat{\beta}^{W}-\hat{\beta}^{M}\right)\right\rfloor$.

13 Another approach is to estimate a non-linear decomposition using the full sample as described in Fairlie (2005) and Fairlie and Robb (2008). Disclosure restrictions using the confidential data prevented us from removing this output for the female/ male gaps in business outcomes.
}

observable characteristics or "endowments." We do not report estimates for the second or "unexplained" component of the decomposition because it partly captures contributions from group differences in unmeasurable characteristics and it is sensitive to the choice of left-out categories, making the results difficult to interpret (see Jones 1983; Cain 1986 for more discussion). Another issue that arises in calculating the decomposition is the choice of coefficients or weights for the first component of the decomposition. The first component can be calculated using either the white or minority coefficients, often providing different estimates, which is the familiar index problem with the Blinder-Oaxaca decomposition technique. An alternative method is to weight the first term of the decomposition expression using coefficient estimates from a pooled sample of the two groups (see Oaxaca and Ransom 1994 for example). We follow this approach to calculate the decompositions by using coefficient estimates from a logit regression that includes a sample of both men and women, as reported in Tables 2 and 3. As noted above, the coefficient estimates do not differ substantially by gender.

The contribution from gender differences in the characteristics can thus be written as:

$$
\left(\bar{X}^{M}-\bar{X}^{F}\right) \hat{\beta}^{*} \text {. }
$$

where $\bar{X}^{j}$ are means of firm characteristics of gender $j, \hat{\beta}^{*}$ is a vector of pooled coefficient estimates, and 
$j=F$ or $M$ for women and men, respectively. Equation 1 provides an estimate of the contribution to the gender gap of gender differences in the entire set of independent variables. Separate calculations are made to identify the contribution of group differences in specific variables to the gap.

Table 6 reports estimates from this procedure for decomposing the large female/male gaps in small business outcomes discussed above. The separate contributions from gender differences in each set of independent variables are reported. Gender differences in the racial ownership of the firm are relatively small and do not contribute substantially to the gaps in small business outcomes.

Gender differences in education levels explain part of the gap in business outcomes, but the effects are not consistently large. Educational differences explain $11.0 \%$ of the female/male gap in closure rates, but only $0.6 \%$ of the gap in profits. The higher concentration of female business owners in the

Table 6 Decompositions of female/male gaps in small business outcomes Characteristics of Business Owners, 1992

\begin{tabular}{|c|c|c|c|c|}
\hline \multirow[t]{2}{*}{ Decompositions of female/male gaps in small business outcomes } & \multicolumn{4}{|c|}{ Specification } \\
\hline & $(1)$ & (2) & (3) & (4) \\
\hline Dependent variable & Closure & Profits & Employer & Ln Sales \\
\hline Female mean & 0.2441 & 0.1727 & 0.1636 & 9.5733 \\
\hline Male mean & 0.2162 & 0.3642 & 0.2374 & 10.3571 \\
\hline Female/male gap & 0.0279 & -0.1915 & -0.0739 & -0.7839 \\
\hline \multicolumn{5}{|l|}{ Contributions from gender differences in: } \\
\hline \multirow[t]{2}{*}{ Race } & 0.0006 & -0.0028 & -0.0018 & -0.0092 \\
\hline & $2.1 \%$ & $1.4 \%$ & $2.5 \%$ & $1.2 \%$ \\
\hline \multirow[t]{2}{*}{ Marital status } & 0.0006 & -0.0045 & -0.0026 & -0.0030 \\
\hline & $2.1 \%$ & $2.3 \%$ & $3.5 \%$ & $0.4 \%$ \\
\hline \multirow[t]{2}{*}{ Education } & 0.0031 & -0.0011 & -0.0117 & -0.0117 \\
\hline & $11.0 \%$ & $0.6 \%$ & $2.8 \%$ & $1.5 \%$ \\
\hline \multirow[t]{2}{*}{ Region } & 0.0007 & 0.0008 & -0.0003 & 0.0004 \\
\hline & $2.6 \%$ & $-0.4 \%$ & $0.4 \%$ & $-0.1 \%$ \\
\hline \multirow[t]{2}{*}{ Urban } & 0.0005 & 0.0013 & -0.0010 & 0.0030 \\
\hline & $1.8 \%$ & $-0.7 \%$ & $1.4 \%$ & $-0.4 \%$ \\
\hline \multirow[t]{2}{*}{ Prior work experience } & -0.0002 & 0.0011 & 0.0005 & 0.0018 \\
\hline & $-0.7 \%$ & $-0.6 \%$ & $-0.6 \%$ & $-0.2 \%$ \\
\hline \multirow[t]{2}{*}{ Prior work experience in a managerial capacity } & -0.0028 & -0.0011 & -0.002 & -0.0090 \\
\hline & $-10.1 \%$ & $0.6 \%$ & $3.0 \%$ & $1.1 \%$ \\
\hline \multirow[t]{2}{*}{ Prior work experience in a similar business } & 0.0048 & -0.0116 & -0.0049 & -0.0463 \\
\hline & $17.3 \%$ & $6.1 \%$ & $6.6 \%$ & $5.9 \%$ \\
\hline \multirow[t]{2}{*}{ Have a self-employed family member } & 0.0003 & -0.0002 & $0.0003-0$ & 0.0005 \\
\hline & $1.0 \%$ & $0.1 \%$ & $0.0 \%$ & $-0.1 \%$ \\
\hline \multirow[t]{2}{*}{ Prior work experience in a family member's business } & 0.0019 & -0.0015 & -0.0026 & -0.0175 \\
\hline & $7.0 \%$ & $0.8 \%$ & $3.5 \%$ & $2.2 \%$ \\
\hline \multirow[t]{2}{*}{ Inherited business } & 0.0003 & -0.0003 & -0.0006 & -0.0040 \\
\hline & $1.1 \%$ & $0.2 \%$ & $0.8 \%$ & $0.5 \%$ \\
\hline \multirow[t]{2}{*}{ All included variables } & 0.0098 & -0.0198 & -0.0176 & -0.0950 \\
\hline & $35.1 \%$ & $10.4 \%$ & $23.9 \%$ & $12.1 \%$ \\
\hline
\end{tabular}

The samples and regression specifications are the same as those used in Table 2

See text for more details on calculation of contribution estimates 
middle of the educational distribution, relative to male business owners, appears to have a modest negative effect on business performance.

The lower percentage of female business owners who are married explains a small share of the business outcome gaps. Female business owners are less likely to be married than are male owners, and marriage is associated with business success. These results are difficult to interpret, however, given potentially different lifestyle choices that are interrelated with marriage. Regional and urbanicity differences are small between female and male firms, resulting in essentially zero contribution estimates. Gender differences in the amount of prior work experience and management experience are small, and thus do not have large effects or mixed effects across specifications.

As reported in Table 4, female business owners have the same likelihood of having a self-employed family member as male business owners. The result is that gender differences in this factor do not contribute to female/male disparities in survival, profits, employment, and sales. Likewise, gender differences in business inheritances also do not contribute to differences in business performance. In contrast, we find larger differences between female and male owners in whether they worked in a family business. Thus, the explanatory power of gender differences in prior work experience in a family member's business is stronger (although not large). Gender differences in this variable explain $0.8-7.0 \%$ of the female/male gaps in small business outcomes. Apparently, the lack of work experience in family businesses among future female business owners, perhaps by restricting their acquisition of general and specific business human capital, limits the successfulness of their businesses relative to men's businesses.

Providing some additional evidence on this point, gender differences in prior work experience in a business providing similar goods and services consistently explain part of the gaps in outcomes. Although the coefficient estimates in the small business outcome regressions were generally similar in magnitude to coefficient estimates on the family business work experience variable, the contributions from gender differences are larger. The gender disparity in the percentage of owners that worked in a business with similar goods and services is larger than the disparity in the percentage of owners that worked in a family business. These differences in prior work experience provide the largest contribution of any reported factor in the table, explaining from $5.9 \%$ to $17.3 \%$ of the gaps in business outcomes. The lack of prior work experience in a similar business among female owners may limit their acquisition of general and specific business human capital that is important for running successful businesses.

\subsection{Startup capital differences}

Table 7 reports the results of decompositions that include contributions from gender differences in startup capital and industry. Female-owned firms have less startup capital than male-owned firms. For example, $13.3 \%$ of female-owned businesses required at least $\$ 25,000$ in startup capital, compared with $17.7 \%$ of male-owned businesses. These gender differences in startup capital generally explain a large portion of the female/male gaps in small business outcomes. The contribution estimates range from $9.8 \%$ to $44.7 \%$. Lower levels of startup capital among female-owned firms are associated with less successful businesses (Fig. 3).

An important question is whether these lower levels of startup capital are related to difficulties in obtaining funding because of borrowing constraints. Brush et al. (2004) note that female entrepreneurs have access to different business and investment social networks than male entrepreneurs. Another possibility is that female-owned businesses use less startup capital for lifestyle reasons or different goals about future growth of the business. All of these factors may contribute to the lower levels of startup capital among female business owners than among male business owners. In the end, however, we cannot rule out the possibility that gender disparities in startup capital may also be caused by differences in the types, scale or potential successfulness of businesses that female entrepreneurs start. $^{14}$

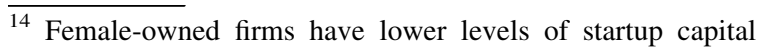
across most major industries, with the exceptions being agriculture and construction-industries with very few women-owned businesses (U.S. Census Bureau 1997).
} 
Table 7 Decompositions of female/male gaps in small business outcomes Characteristics of Business Owners, 1992

\begin{tabular}{|c|c|c|c|c|}
\hline \multirow[t]{2}{*}{ Decompositions of female/male gaps in small business outcomes } & \multicolumn{4}{|c|}{ Specification } \\
\hline & $(1)$ & (2) & (3) & (4) \\
\hline Dependent variable & Closure & Profits & Employer & Ln sales \\
\hline Female mean & 0.2441 & 0.1727 & 0.1636 & 9.5733 \\
\hline Male mean & 0.2162 & 0.3642 & 0.2374 & 10.3571 \\
\hline Female/male gap & 0.0279 & -0.1915 & -0.0739 & -0.7839 \\
\hline \multicolumn{5}{|l|}{ Contributions from gender differences in: } \\
\hline \multirow[t]{2}{*}{ Race } & 0.0003 & -0.0025 & -0.0012 & -0.0056 \\
\hline & $1.0 \%$ & $1.3 \%$ & $1.6 \%$ & $0.7 \%$ \\
\hline \multirow[t]{2}{*}{ Marital status } & 0.0007 & -0.0055 & -0.0024 & -0.0010 \\
\hline & $2.4 \%$ & $2.9 \%$ & $3.2 \%$ & $0.1 \%$ \\
\hline \multirow[t]{2}{*}{ Education } & 0.0046 & -0.0004 & -0.0028 & -0.0146 \\
\hline & $16.4 \%$ & $0.2 \%$ & $3.8 \%$ & $1.9 \%$ \\
\hline \multirow[t]{2}{*}{ Region } & 0.0007 & 0.0008 & -0.0003 & 0.0011 \\
\hline & $2.4 \%$ & $-0.4 \%$ & $0.4 \%$ & $-0.1 \%$ \\
\hline \multirow[t]{2}{*}{ Urban } & 0.0002 & 0.0018 & -0.0004 & 0.0055 \\
\hline & $0.9 \%$ & $-0.7 \%$ & $0.6 \%$ & $-0.7 \%$ \\
\hline \multirow[t]{2}{*}{ Prior work experience } & -0.0003 & 0.0011 & 0.0008 & 0.0032 \\
\hline & $-1.2 \%$ & $-0.6 \%$ & $-1.1 \%$ & $-0.4 \%$ \\
\hline \multirow[t]{2}{*}{ Prior work experience in a managerial capacity } & -0.0036 & -0.0003 & -0.0009 & -0.0017 \\
\hline & $-12.8 \%$ & $0.2 \%$ & $1.2 \%$ & $0.2 \%$ \\
\hline \multirow[t]{2}{*}{ Prior work experience in a similar business } & 0.0057 & -0.0109 & -0.0048 & -0.0462 \\
\hline & $20.6 \%$ & $5.7 \%$ & $6.5 \%$ & $5.9 \%$ \\
\hline \multirow[t]{2}{*}{ Have a self-employed family member } & 0.0002 & 0.00020 & 0.0001 & 0.0009 \\
\hline & $0.9 \%$ & $0.0 \%$ & $-0.1 \%$ & $-0.1 \%$ \\
\hline \multirow[t]{2}{*}{ Prior work experience in a family member's business } & 0.0015 & -0.0010 & -0.0016 & -0.0016 \\
\hline & $5.4 \%$ & $0.5 \%$ & $2.2 \%$ & $1.4 \%$ \\
\hline \multirow[t]{2}{*}{ Inherited business } & 0.0002 & -0.0004 & -0.0007 & -0.0004 \\
\hline & $0.8 \%$ & $0.2 \%$ & $0.9 \%$ & $0.5 \%$ \\
\hline \multirow[t]{2}{*}{ Startup capital } & 0.0125 & -0.0188 & -0.0236 & -0.1178 \\
\hline & $44.7 \%$ & $9.8 \%$ & $32.0 \%$ & $15.0 \%$ \\
\hline \multirow[t]{2}{*}{ Industry } & -0.0010 & -0.0089 & -0.0 & -0.0374 \\
\hline & $-3.7 \%$ & $4.7 \%$ & $4.1 \%$ & $4.8 \%$ \\
\hline \multirow[t]{2}{*}{ All included variables } & 0.0217 & -0.0449 & -0.0409 & -0.2284 \\
\hline & $77.8 \%$ & $23.5 \%$ & $55.4 \%$ & $29.1 \%$ \\
\hline
\end{tabular}

The samples and regression specifications are the same as those used in Table 4

See text for more details on calculation of contribution estimates

\subsection{Industry differences}

Female and male firms concentrate in different industries. Female firms are underrepresented in construction and overrepresented in retail trade, personal services and professional services, relative to male firms. These industry differences are generally associated with worse outcomes among female-owned firms. The decomposition estimates indicate that industry differences explain $4.1-4.8 \%$ of the gender differences in business outcomes, but for closure, these differences provide a negative contribution of $3.7 \%$, suggesting that female businesses have a favorable industry distribution for this 
Fig. 3 Startup capital by gender. Source: CBO 1992 survey (color figure online)

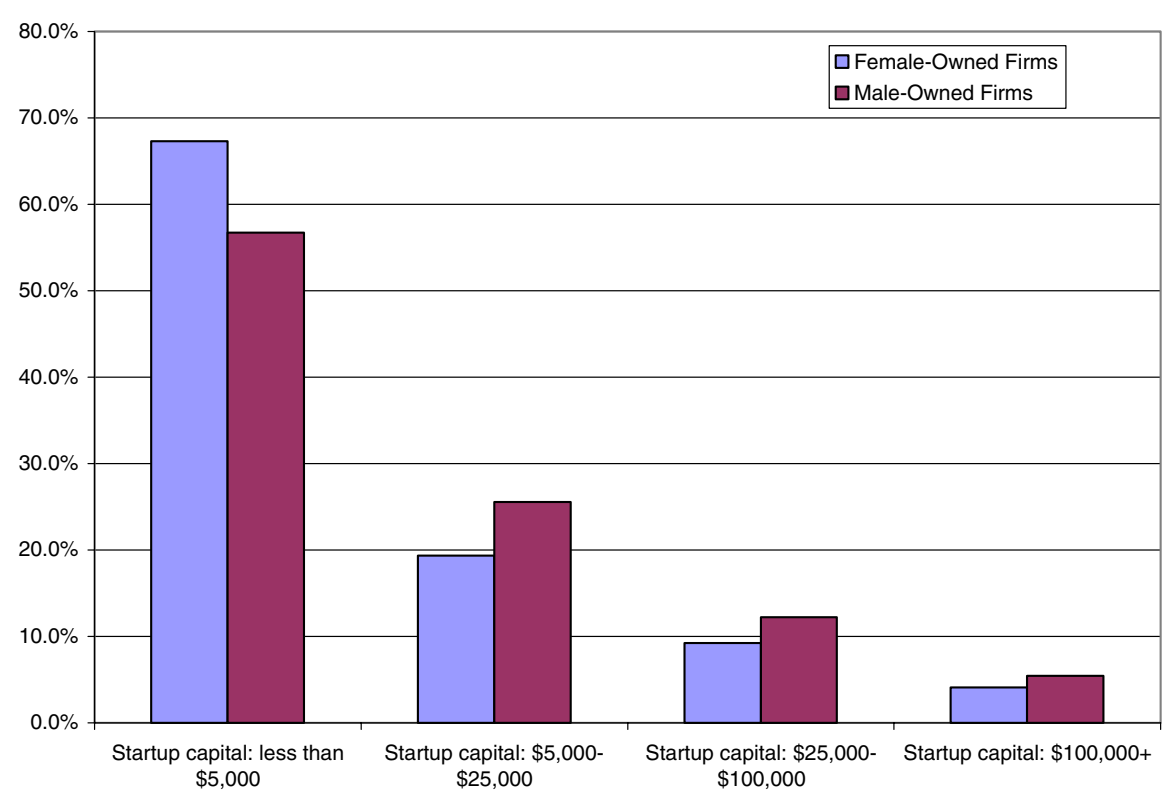

outcome. Differences in industry distributions may be due to capital constraints, skill differences, discrimination, and differences in preferences, making it difficult to interpret these results. Furthermore, the inconsistency of the direction of the contribution of gender differences in industry distributions suggests that it is not one of the major factors affecting gender differences in outcomes.

Overall, gender differences in the explanatory variables explain a large percentage of the total female/male gaps in small business outcomes. They explain three quarters of the gender gap in the closure rate and more than half of the gap in the employer rate. For profits and sales, gender differences in the explanatory variables explain one quarter of the gaps. Decomposition techniques generally do not explain a large share of gaps in outcomes. The remaining or "unexplained" portion of the gender gaps in small business outcomes may be due to the omission of important unmeasurable or difficult-to-measure factors, such as preferences for growth, risk aversion, and networks, and lending discrimination and consumer discrimination against female-owned firms.

\section{Other potential explanations}

Differences between male- and female-owned businesses in terms of closure rates, profits, employment, and sales may be related to barriers to success for female-owned businesses. For example, Brush et al. (2004) note that female entrepreneurs have access to different business and investment social networks than male entrepreneurs. ${ }^{15}$ Differences in business outcomes, however, may also be related to gender differences in the goals and types of businesses and preferences for level of work activity. Previous research indicates that women who are married to self-employed men are more likely to be selfemployed or enter self-employment and that the choice of self-employment is partly driven by the desire for flexible schedules and other family-related reasons for women more than men (Devine 1994; Boden 1996, 1999; Carr 1996; Bruce 1999; Robb 2000; Lohmann 2001; Lombard 2001). Female owners may have different goals for business growth and tolerances for taking risks associated with business growth (Cliff 1998).

\subsection{Hours worked}

Are female-owned businesses less successful than male-owned businesses because female owners typically work fewer hours? We are concerned about

\footnotetext{
15 Also, see Gatewood, et al. (2003) and Parker (2004) for recent reviews of the literature and Coleman (2001) for a discussion of constraints faced by women-owned firms.
} 
including hours worked in the regression models or using them to create adjusted outcome measures, such as firm profits or sales per hour, because it assumes away the possibility that limited demand for products and services is responsible for why some business owners work less than full-time. We would be implicitly assuming that all business owners work their desired amount of hours, which is unlikely to be the case. But, one problem is that women and men may differ in preferences for how much they want to work, and thus hours could be seen more as an explanatory variable.

Given these concerns, it is useful to examine whether female owners work more hours on average than other owners. As noted above, our sample excludes owners with fewer than $10 \mathrm{~h}$ worked per week, but there might important gender differences in part-time work. ${ }^{16} \mathrm{We}$ are also interested in focusing on whether female owners are less likely to work long hours exceeding $40 \mathrm{~h} /$ week. To investigate this issue, we compare hours worked for female and male firms from published estimates from the CBO.

Female business owners are more likely than male owners to work between 10 and $30 \mathrm{~h} /$ week. We find that $26.2 \%$ of female business owners work 10-29 h/ week, compared with $18.2 \%$ of male business owners. We also find that female business owners are less likely to work long hours of 50 or more per week, but the difference is not large. Among female business owners, $22.2 \%$ work 50 or more hours per week compared with $27.6 \%$ of male business owners. Overall, however, the clear majority of female business owners work at least $30 \mathrm{~h} /$ week after we remove those working fewer than $10 \mathrm{~h} /$ week from our sample.

Another interesting finding is that regardless of hours worked, female-owned businesses have lower sales than businesses owned by men. Businesses owned by men were more likely than businesses owned by women to have receipts of US $\$ 100,000$ or more across all the hours worked categories. Thus, differences in hours worked may explain part of the gaps in business outcomes, but definitely not all of the gaps.

\footnotetext{
$\overline{16}$ Our sample also has the condition of working at least 12 weeks during the year. An examination of weeks worked distributions by gender does not reveal large differences (U.S. Census Bureau 1997).
}

\subsection{Motivations for starting businesses}

Published estimates from the $\mathrm{CBO}$ provide some additional information on motivations and preferences about business ownership. Male and female business owners have very similar methods of acquiring the business. For both groups, most businesses were founded by the owner. A slightly higher percentage of male owners received businesses as a transfer of ownership or gift, but a similarly low percentage received the business as an inheritance. Men and women do not differ in how they acquired the business.

Published estimates from the CBO are also available on the reason for becoming an owner of the business. Unfortunately, because these estimates are from published sources, we cannot remove the low hours owners that we excluded from the main analysis when using the microdata. We find the three main reasons that owners report becoming a business owner are: to have a primary source of income, to have a secondary source of income, and to be [one's] own boss. Men are more likely to report owning a business to have a primary source of income than are women, and women are more likely to report owning a business to have a secondary source of income. The wording of the question does entirely clarify whether this refers to family income or personal earnings (i.e., secondary jobs such as consulting). In any case, it suggests that female owners may differ from male owners in how they view their business for providing income. These gender differences may have implications for risk/return tradeoff choices, and thus business performance disparities. ${ }^{17}$

Twenty-four percent of male owners report owning a business to be their own boss, compared with $20 \%$ of female owners. This small difference provides some evidence that motivations do not differ substantially between men and women. One major difference between men and women is the percentage reporting owning a business to meet family responsibilities. Slightly more than $12 \%$ of female owners report owning a business to meet family responsibilities,

\footnotetext{
17 Closure rates are higher among female owners than male owners and controlling for industry choices does not unambiguously reduce gender disparities in business outcomes. This finding provides some suggestive evidence that female owners are not choosing to start less risky and thus lower return types of businesses.
} 
which is double the percentage for male owners. Overall, there are some differences in motivations for starting businesses between male and female owners, but these differences are not large. For example, even the relatively large gender difference in starting a business to meet family responsibilities accounts for only $6 \%$ more female-owned firms than male-owned firms in total.

\section{Conclusions}

Estimates from the $\mathrm{CBO}$ indicate that female-owned businesses have worse average outcomes than maleowned businesses. Female firms are $12.9 \%$ more likely to close, $52.6 \%$ less likely to have profits of at least US\$10,000, and $31.1 \%$ less likely to hire employees than male firms. They also have mean annual sales that are roughly $80 \%$ lower than the mean sales of male-owned firms. Even conditioning on hours, we find that women-owned businesses have much lower levels of sales than businesses owned by men. Female business owners are less likely to have very low levels of education than male business owners, but they are also less likely to have graduate degrees.

Female business owners are also less likely to have prior work experience in a family business and prior work experience in a business providing similar goods and services. Because of these differences in prior work experience, female business owners may have had fewer opportunities to acquire the specific and general business human capital that is important for running successful businesses. Female businesses are also found to have relatively low levels of startup capital. Estimates from the CBO indicate that $13.3 \%$ of female-owned businesses started with more than $\$ 25,000$ in capital, compared with $17.7 \%$ of maleowned firms. Finally, female businesses locate in different industries than male businesses. Female businesses are more likely to be in retail trade, personal services and professional services, and less likely to be in construction.

We use a decomposition technique to measure the contribution of gender differences in firm and owner characteristics to differences in business outcomes between female- and male-owned businesses. The decomposition estimates indicate that female-owned businesses are less successful than male-owned businesses because they use less startup capital, have less prior work experience in a similar business, and less prior work experience in a family business. Gender differences in industry distributions, however, are not a major explanation for female/male gaps in business outcomes.

As reported above, evidence from the USA and several other countries suggests that women are less likely than men to report having a desire for selfemployment, although the difference is not large (Kourilsky and Walstad 1998; Blanchflower et al. 2001). In the end, unobservable factors, such as different preferences, discrimination, and risk aversion, may be responsible for low levels of female entrepreneurship and lower returns (Bird and Brush 2002; Carter et al. 2003). From a policy perspective, however, these are difficult to address. Policies that increase human capital and access to financial capital, such as entrepreneurial training and loan assistance programs, are easier to implement and expand.

Acknowledgments This research was partially funded by the Russell Sage Foundation and Kauffman Foundation. The research in this paper was conducted while the authors were Special Sworn Status researchers of the U.S. Census Bureau at the Center for Economic Studies and California Research Data Center at U.C. Berkeley. This paper has been screened to insure that no confidential data are revealed. The data can be obtained at a Census Research Data Center or at the Center for Economic Studies (CES) only after approval by the CES and IRS. See http://www.ces.census.gov/ for details on the application and approval process. The views expressed here are solely the responsibility of the authors and should not be interpreted as reflecting the views of the Russell Sage Foundation, the Kauffman Foundation, the U.S. Census Bureau, or the Board of Governors of the Federal Reserve System. We thank Will Jackson and participants in the 2008 UNC Minority Entrepreneurship Conference for comments and suggestions.

Open Access This article is distributed under the terms of the Creative Commons Attribution Noncommercial License which permits any noncommercial use, distribution, and reproduction in any medium, provided the original author(s) and source are credited. 


\section{Appendix Table 8}

Table 8 Means of analysis variables by gender Characteristics of Business Owners, 1992

\begin{tabular}{|c|c|c|}
\hline & $\begin{array}{l}\text { Female- } \\
\text { owned }\end{array}$ & $\begin{array}{l}\text { Male- } \\
\text { owned }\end{array}$ \\
\hline $\begin{array}{l}\text { Firm no longer operating in } 1996 \\
\quad \text { (Closure) }\end{array}$ & $24.4 \%$ & $21.6 \%$ \\
\hline Net profit of at least US $\$ 10,000$ & $17.3 \%$ & $36.4 \%$ \\
\hline One or more paid employees & $16.4 \%$ & $23.7 \%$ \\
\hline Log sales & 9.57 & 10.36 \\
\hline Married & $76.4 \%$ & $81.7 \%$ \\
\hline Never married & $12.5 \%$ & $15.0 \%$ \\
\hline Previously married & $20.8 \%$ & $12.8 \%$ \\
\hline High school dropout & $8.3 \%$ & $11.6 \%$ \\
\hline High school graduate & $25.3 \%$ & $25.6 \%$ \\
\hline Some college & $33.7 \%$ & $29.8 \%$ \\
\hline College graduate & $21.4 \%$ & $18.2 \%$ \\
\hline Graduate school & $11.4 \%$ & $14.8 \%$ \\
\hline New England & $5.3 \%$ & $6.1 \%$ \\
\hline Middle Atlantic & $14.1 \%$ & $14.7 \%$ \\
\hline East North Central & $15.1 \%$ & $15.7 \%$ \\
\hline West North Central & $7.5 \%$ & $8.0 \%$ \\
\hline South Atlantic & $18.3 \%$ & $15.4 \%$ \\
\hline East South Central & $4.9 \%$ & $5.0 \%$ \\
\hline West South Central & $9.9 \%$ & $11.0 \%$ \\
\hline Mountain & $6.9 \%$ & $6.4 \%$ \\
\hline Pacific & $18.1 \%$ & $17.7 \%$ \\
\hline Urban & $77.7 \%$ & $74.7 \%$ \\
\hline No previous work experience & $7.4 \%$ & $6.0 \%$ \\
\hline Prior work experience: 1 year & $7.7 \%$ & $7.1 \%$ \\
\hline Prior work experience: $2-5$ years & $16.2 \%$ & $16.6 \%$ \\
\hline Prior work experience: $6-9$ years & $14.6 \%$ & $15.4 \%$ \\
\hline Prior work experience: $10-19$ years & $30.3 \%$ & $28.9 \%$ \\
\hline $\begin{array}{l}\text { Prior work experience: } 20 \text { years or } \\
\text { more }\end{array}$ & $23.9 \%$ & $26.0 \%$ \\
\hline $\begin{array}{l}\text { Prior work experience in a managerial } \\
\text { capacity }\end{array}$ & $52.3 \%$ & $56.6 \%$ \\
\hline $\begin{array}{l}\text { Prior work experience in a similar } \\
\text { business }\end{array}$ & $42.5 \%$ & $53.8 \%$ \\
\hline Have a self-employed family member & $50.6 \%$ & $52.0 \%$ \\
\hline $\begin{array}{l}\text { Prior work experience in a family } \\
\text { member's business }\end{array}$ & $19.4 \%$ & $24.0 \%$ \\
\hline Inherited business & $1.4 \%$ & $1.7 \%$ \\
\hline Startup capital: less than US $\$ 5,000$ & $67.3 \%$ & $56.7 \%$ \\
\hline Startup capital: US $\$ 5,000-\$ 25,000$ & $19.3 \%$ & $25.5 \%$ \\
\hline Startup capital: US $\$ 25,000-\$ 100,000$ & $9.2 \%$ & $12.3 \%$ \\
\hline
\end{tabular}

Table 8 continued

\begin{tabular}{lrr}
\hline & $\begin{array}{l}\text { Female- } \\
\text { owned }\end{array}$ & $\begin{array}{l}\text { Male- } \\
\text { owned }\end{array}$ \\
\hline Startup capital: US\$100,000+ & $4.1 \%$ & $5.5 \%$ \\
Agricultural services & $1.7 \%$ & $3.2 \%$ \\
Construction & $3.3 \%$ & $16.3 \%$ \\
Manufacturing & $2.9 \%$ & $3.5 \%$ \\
Wholesale & $3.0 \%$ & $3.8 \%$ \\
Retail & $18.9 \%$ & $13.1 \%$ \\
FIRE & $10.5 \%$ & $9.3 \%$ \\
Transportation, communications, and & $2.5 \%$ & $5.0 \%$ \\
$\quad$ public utilities & $30.6 \%$ & $24.2 \%$ \\
Personal services & $23.0 \%$ & $17.2 \%$ \\
Professional services & $3.7 \%$ & $4.2 \%$ \\
Uncoded industry & 13,918 & 24,102 \\
Sample size & & \\
\hline
\end{tabular}

The sample includes businesses that are classified by the IRS as individual proprietorships or self-employed persons, partnerships, and subchapter S corporations, have sales of US $\$ 500$ or more, and have at least one owner who worked at least 12 weeks and $10 \mathrm{~h} /$ week in the business

All estimates are calculated using sample weights provided by the $\mathrm{CBO}$

\section{References}

Aldrich, H., \& Kim, P. (2007). A life course perspective on occupational inheritance: self-employed parents and their children. In M. Ruef \& M. Lounsbury (Eds.), Research on the sociology of organizations (pp. 33-82). Amsterdam: Elsevier.

Aldrich, H., Renzulli, L., \& Langton, N. (1998). Passing on privilege: Resources provided by self-employed parents to their self-employed children. In K. T. Leicht (Ed.), Research in social stratification and mobility (pp. 291317). Stamford, CT: JAI Press.

Aronson, R. (1991). Self-employment: A labor market perspective. Ithaca: ILR Press.

Astebro, T., \& Bernhardt, I. (2003). Start-up financing, owner characteristics and survival. Journal of Economics and Business, 55(4), 303-320.

Bates, T. (1990). The characteristics of business owners data base. Journal of Human Resources, 25(4), 752-756.

Bates, T. (1997). Race, self-employment \& upward mobility: An illusive American dream. Washington D.C./Baltimore: Woodrow Wilson Center Press/John Hopkins University Press.

Bird, B., \& Brush, C. (2002). A gendered perspective on organizational creation. Entrepreneurship Theory and Practice, 26(3), 41-65.

Blanchflower, D., Oswald, A., \& Stutzer, A. (2001). Latent entrepreneurship across nations. European Economic Review, 45, 680-691. 
Blinder, A. (1973). Wage discrimination: Reduced form and structural variables. Journal of Human Resources, 8, 436455.

Boden, R. (1996). Gender and self-employment selection: An empirical assessment. Journal of Socio-Economics, 25(6), 671-682.

Boden, R. (1999). Flexible working hours, family responsibilities, and female self-employment: Gender differences in self-employment selection. The American Journal of Economic Sociology, 58(1), 71-76.

Boden, R., \& Nucci, A. (2000). On the survival prospects of men's and women's new business ventures. Journal of Business Venturing, 4, 347-362.

Bruce, D. (1999). Do husbands matter? Married women entering self-employment. Small Business Economics, 13, 317-329.

Brush, C., Carter, N., Gatewood, E., Greene, P., \& Hart, M. (2004). Gatekeepers of venture growth: A Diana Project report on the role and participation of women in the venture capital industry. Kansas City: Kauffman Foundation.

Cain, G. (1986). The economic analysis of labor market discrimination: A survey. In O. Ashenfelter \& R. Laynard (Eds.), Handbook of labor economics (Vol. 1, pp. 693781). Amsterdam: Elsevier Science Publishers.

Carr, D. (1996). Two paths to self-employment? women's and men's self-employment in the United States, 1980. Work and Occupations, 23, 26-53.

Carter, N., Gartner, W., Shaver, K., \& Gatewood, E. (2003). The career reasons of nascent entrepreneurs. Journal of Business Venturing, 18, 13-29.

Cliff, J. (1998). Does one size fit all? Exploring the relationship between attitudes towards growth, gender, and business size. Journal of Business Venturing, 13, 523-542.

Coleman, S. (2001). Constraints faced by women small business owners: Evidence from the data. Paper presented at the United States Association for Small Business and Entrepreneurship annual meetings. Washington D.C.: United States Association for Small Business and Entrepreneurship

Devine, T. (1994). Characteristics of self-employed women in the United States. Monthly Labor Review, 117(3), $20-34$.

Fairlie, R. (2005). An extension of the Blinder-Oaxaca decomposition technique to logit and probit models. Journal of Economic and Social Measurement, 30(4), $305-316$.

Fairlie, R. (2006). Entrepreneurship among disadvantaged groups: Women, minorities and the less educated. In S. C. Parker, J. Zoltan, \& D. R. Audretsch (Eds.), International handbook series on entrepreneurship (Vol. 2, pp. 437475). New York: Springer.

Fairlie, R., \& Robb, A. (2007a). Families, human capital, and small businesses: Evidence from the characteristics of business owners survey. Industrial and Labor Relations Review, 60(2), 225-245.

Fairlie, R., \& Robb, A. (2007b). Why are black-owned businesses less successful than white-owned businesses: The role of families, inheritances, and business human capital. Journal of Labor Economics, 25(2), 289-323.
Fairlie, R., \& Robb, A. (2008). Race and entrepreneurial success: Black-, Asian-, and White-owned businesses in the United States. Cambridge: MIT Press.

Gatewood, E. G., Carter, N. M., Brush, C. G., Greene, P. G., \& Hart, M. M. (2003). Women entrepreneurs, their ventures, and the venture capital industry: An annotated bibliography. Stockholm: ESBRI.

Headd, B. (1999). The characteristics of business owners database, 1992. U.S. Census Bureau, Center for Economic Studies, working paper series, CES-WP-99-8. Washington D.C.: U.S. Census Bureau, Center for Economic Studies

Headd, B. (2003). Redefining business success: Distinguishing between closure and failure. Small Business Economics, 21(1), 51-61.

Hundley, G. (2000). Male/female earnings differences in selfemployment: The effects of marriage, children, and the household division of labor. Industrial and Labor Relations Review, 54(1), 95-104.

Jones, F. (1983). On decomposing the wage gap: A critical comment on Blinder's method. Journal of Human Resources, 18(1), 126-130.

Kalleberg, A., \& Leicht, K. (1991). Gender and organizational performance: Determinants of small business survival and success. Academy of Management Journal, 34(1), 136161.

Kourilsky, M., \& Walstad, W. (1998). Entrepreneurship and female youth: Knowledge, attitudes, gender differences, and educational practices. Journal of Business Venturing, $13,77-88$.

Lentz, B., \& Laband, D. (1990). Entrepreneurial success and occupational inheritance among proprietors. Canadian Journal of Economics, 23(3), 563-579.

Lohmann, H. (2001). Self-employed or employee, full-time or part-time? Gender differences in the determinants and conditions for self-employment in Europe and the US. Mannheim Centre for European Social Research working paper 38. Mannheim: Mannheim Centre for European Social Research.

Lombard, K. (2001). Female self-employment and demand for flexible, nonstandard work schedules. Economic Inquiry, 39(2), 214-237.

Oaxaca, R. (1973). Male-female wage differentials in urban labor markets. International Economic Review, 14, 693709.

Oaxaca, R., \& Ransom, M. (1994). On discrimination and the decomposition of wage differentials. Journal of Econometrics, 61, 5-21.

OECD. (2002). OECD labour force statistics. Geneva: OECD

Parker, S. (2004). The economics of self-employment and entrepreneurship. Cambridge, MA: Cambridge University Press.

Robb, A. (2000). The role of race, gender and discrimination in business survival. $\mathrm{PhD}$ dissertation. Ann Arbor, MI: University of Michigan Press.

Robb, A. (2002). Entrepreneurial performance by women and minorities: The case of new firms. Journal of Developmental Entrepreneurship, 7(4), 383-397.

Robb, A. (2008). An investigation of new firm performance by owner race, ethnicity, and gender. Working paper. 
Robb, A., \& Wolken, J. (2002). Firm, owner, and financing characteristics: Differences between female- and maleowned small businesses. Federal Reserve working paper series: 2002-18. Washington D.C.: Federal Reserve

Rosa, P., Carter, S., \& Hamilton, D. (1996). Gender as a determinant of small business performance: Insights from a British study. Small Business Economics, 8, 463-478.

Srinivasan, R., Woo, C., \& Cooper, A. (1994). Performance determinants for male and female entrepreneurs. Working paper 1053. West Layfette, IN: Purdue University.

U.S. Bureau of Labor Statistics. (2004). Median weekly earnings of full-time wage and salary workers by selected characteristics, labor force statistics from the current population survey. Available at: http://www.bls.gov/cps/ cpsaat37.pdf.

U.S. Census Bureau. (1996). 1992 Economic census: Survey of minority-owned business enterprises, Asians and Pacific Islanders, American Indians, and Alaska Natives. Washington, DC: U.S. Government Printing Office.

U.S. Census Bureau. (1997). 1992 Economic census: Characteristics of business owners. Washington, DC: U.S. Government Printing Office.

U.S. Department of Education. (2002). Digest of education statistics, 2002. Washington, DC: National Center for Education Statistics. 